\title{
DOUBLE EFFECT AND BLACK REVENGE IN LESSING'S THE GRASS IS SINGING
}

\author{
Pedram Lalbakhshe \\ Razi University, Iran \\ Mohammad Javad Haj' jari \\ Razi University, Iran
}

\begin{abstract}
A white woman's murder by a black man, as depicted in Doris Lessing's The Grass IS Singing, incorporates the revengeful act of an abandonment-neurotic black servant against a white female master with tactile delirium in the course of a paradoxical relationship of love and hate. The final homicide and the consequent act of surrender by Moses, the murderer, convey his paradoxical attitude toward his white masterbeloved. This attitude begins with hatred, intensifies with mutual affection, and ends in murder. Focusing on the interracial revenge that takes place in the novel under study, the authors of this paper argue that Moses' motivation in killing Mary originates from the ambivalence of his state of living under colonization and his learnings in Christianity, struggling with the Double-Effect Reasoning inaugurated by and in defense of black honor or negritude. As such, Moses' sense of guilt and his subsequent surrender are the consequences of traditional and colonial internalization of sin, already present in him as a native of his revenge or honorbased society, influenced by Lobengula's rule in which the criminal submits to punishment willingly, as well as missionary teachings. Through an interdisciplinary link between the Double-Effect Reasoning and the psychoanalytical perspective to the black problem promoted by Frantz Fanon, The Grass Is Singing thus seems to exempt Moses in his crime against the white race, represented by Mary, as well as to justify Moses self-surrender in defense of negritude and black honor.
\end{abstract}

Keywords: Doris Lessing; Colonization; Double Effect; Black Ethics and Black Revenge. 


\section{Introduction}

Double-Effect Reasoning (DER), the Principle of Double Effect (PDE), the Doctrine of Double Effect (DDE) or the Rule of Double Effect (RDE) (Cavanaugh xx), is often used in discussing the permissibility of an action which incorporates a serious harm or death of a human being as a side effect of achieving a good end. Such harm is sometimes merely a "foreseen side effect" or "double effect" in bringing about a good end, although it is impermissible to cause the same harm intentionally as a means to the same good end (McIntyre, 2011: 8). Aquinas, following St. Augustine, is credited with introducing DER in the Summa Theologica, defending homicidal self-defense which happens unintentionally (McIntyre, 2011: 8 \& Cavanaugh, 2006: 1):

Nothing prevents one act from having two effects, of which only one is intended, the other being praeter intentionem [outside the moral intention]. Now moral acts receive their character according to that which is intended, not, however, from that which is praeter intentionem, since this is accidental. (Cavanaugh, 2006: 3)

Aquinas expands this idea to justify the foreseen-but-not-intended murder of an aggressor. Later elaborations of the principle focus on the general distinction between "causing a morally grave harm as a side effect of pursuing a good end" and "causing a harm as a means of pursuing a good end" (McIntyre, 2011: 9). In general, DER is used to analyze "exceptional cases" in which a good end cannot be actualized without a bad effect (Cavanaugh, 2006: 46). Examples include hard cases of murder, euthanasia, abortion, and terror bombing.

One of such hard cases is revenge: killing or causing harm to an opponent for a former insult or harm, physical or spiritual. But killing is not permissible, being immoral intrinsically. However, it is revenge as a "retributive punishment" (Kaufman, 2013: 95), which makes use of DER to justify the harm against the opponent. "Retributive punishment" combines revenge with legal punishment to legalize the punishment of an opponent for an immoral action (Cavanaugh Passim). Hence, the punishment of a murderer by jurisdiction in favor of the victim's family instead of the latter's personal revenge against the murderer. Related to this issue is "moral psychology" or "action theory" which investigates the what-ness of an action by focusing on its mental features such as "knowledge, belief, desire, will, intent, ends, and means." Therefore, the question is what makes an act of killing unjust? The agent's intention is of utmost concern. There is a distinction between "intending to kill or gravely harm" and doing something with the inevitable-but-not-intended 
death or grievous harm to the innocent (xix).

An even harder case, and the subject of this study, is interracial revenge in communities filled with tensions between black and white people. It was most evident in colonial Africa where black slaves suffered under white cruelty, and, therefore, black revenge was not infrequent. In such oppressive societies, black revolt and rage were inevitable.

Involved in such violence was Southern Rhodesia, now Zimbabwe, which suffered from the "minority rule" of whites who were often brutal. Native workers were assaulted mostly because of their resistance against racism and the economic pressures under which they had to obey white masters (McCulloch, 2000: 36). The white population in the "racist regime of Rhodesia" was physically and emotionally harsh against the black majority (Kirton, 2010: 45). Settlers in South Rhodesia treated their Kafir laborers as dogs, "to be beaten and cuffed at will" (Hensman, 1900: 169). Occasionally treating certain black individuals fairly, Settlers loathe them in general "to the point of neurosis" (Lessing 92). It is very probable in such circumstances that the black race rises to defend its honor and negritude.

As a literary documentation of interracial tensions, Lessing's The Grass IS Singing (1950) incorporates the murder of a white woman by a black servant as the inevitable interracial violence between black and white people in its South Rhodesian version. As Schlueter says, the heart of the book tells about settlers who refuse to accept natives as human (1973: 9). The murder of Mary Turner, a woman with tactile delirium, by Moses, an abandonment-neurotic black servant, conveys a series of tensions developed into interracial homicide. The question is whether a black man is justified in killing a white woman, the former oppressed and the latter oppressor; one the suffering colonized, the other the cruel colonizer. DER is the medium through which the present study tries to justify such violence. As such, the issue is rendered under the moral-philosophical DER and the postcolonial ethics developed by Franz Fanon to investigate morally and psychologically into Moses' development of mind in killing Mary and his willing surrender.

\section{Discussion}

The Grass Is Singing is one of those novels that, as Alkali et al. introduce them, show "to the world how the genre of African literature is 'an unparalleled laboratory' discovering new issues" (2013 :237). The novel "is very Rhodesian" as it is based on the life of the region in which Lessing grew up (Lessing and Ingersoll, 1994: 131), as well as on the life of someone she knew (ibib. :112). Hence, Lessing's fictional documentation of interracial violence. 'Murderer Mystery' is the initial 
words of the novel which lead us to investigate into Moses' motivation in killing his white female master.

The mutual psychological bond developed between Mary and Moses ends up in the former's murder by the latter. Thus, the murderer's motivation is of utmost importance, especially when it is that of a muscular black man against a white delicate blue-eyed woman. The case shows its complex side when the murderer refrains from escaping and awaits the police to surrender. Accordingly, two sides of the case consist of Moses' motivations in homicide and surrender.

Moses' motivation in murder may initially arise from maltreatment by the white master, especially ignited after the face-whipping scene happened six years before the murder. When Moses is recruited as the houseboy, two years has already passed from the scene where Mary whipped Moses in the face when he stopped working to drink water. But by the time of his selection as the houseboy, Moses is free of that primary contempt against Mary and there seems to be "nothing in his attitude to suggest that he remembered the incident" (Lessing, 1973: 175). Moreover, "about four years" pass before Moses finally murders Mary (220), during which a rather intimate relationship develops between them. There thus must be another reason for his homicide. Peering into Moses' character before and during meeting Mary helps us understand his motivation in killing her. The following sections highlight this issue.

\section{Moses' Negritude}

Moses has been in "Mashonaland" (Lessing, 1973: 14). "Mashona" seems to be a nickname that the native King Lobengula Khumalo (1845-1894) gave the region under his order (Knight-Bruce, 1985: 9). It became part of Southern Rhodesia by 1923 and even before that the region was under the leadership of Lobengula, usually called Matabele in English, who deemed that, in his kingdom, disobeying any social responsibility were punished with death (Dodds Passim). As Lessing says,

The laws were strict: everyone knew what they could or could not do. If someone did an unforgivable thing, [...] he would submit fatalistically to punishment, which was likely to be impalement over an ant-heap on a stake, or something equally unpleasant. 'I have done wrong; and I know it', he might say, 'therefore let me be punished.' Well, it was the tradition to face punishment. (1973: 14) 
Such rules were rooted in the native conceptions of fearlessness and courage. Men in Mashonaland/Mashona were famous for their "courage" (Knight-Bruce, 1985: 9), "strength of character" (ibib. :26). Once in Mashonaland, the Anglican Bishop Knight-Bruce (1853-96) observes that natives of the region were a "subject race" under Lobengula. Thus, their spirit of courage was gone; but there was the possibility of its revival if they were properly treated. Having the sense of cowardice, they were ashamed; but they had still retained "a good deal of savage brutality" (Knight-Bruce, 1985: 9-10). Moses, having lived in Mashonaland, either as a native or settler, might have inherited some of these features. His bodily strength and demeanor reveal his differences from other natives, as he is "decent" (Lessing, 1973: 191), "a good boy" who "works well" (ibid. :220), and a courageous man against insults.

Moses has also been a "mission boy" who knows "too much" (ibid. :191). Mission boys in South Rhodesia were educated based on Christian principles, and thus we can say Moses has some Christian beliefs learned in English. According to Fanon, black schoolboys identified themselves with the explorers, the bringers of civilization, the white men who carried "truth to savages—an all-white truth." The young Negro's identity was thus a subjectively adoption of the attitudes of a white man (2008: 114). Moses' knowledge of English and his Christian training, as part of his new identity, are therefore revealed in his speaking in the language of his masters and his background as a mission boy.

On the other hand, with the development of Christianity in Africa, Africans forgot the functionality of their traditional prayers to their own deities. However, the efficacy of Christianity was also under doubt; when politics entered the scene, Christianity was considered as a peaceful way of keeping colonialism alive. Thus, Africans lost their faith in the religion they could not fully cope with. They now looked back "with admiration" to their old traditions and rituals that Christianity made them forget (Fry, 2000: 111). In a famous native song in South Rhodesia, the land is depicted "as a rich and fertile land" raped by white colonizers, while in essence it is a woman married to the black man. Black men are in fact the true "husbands" of the land and its "great heroes of the past," and Lobengula is the true king. The past is therefore recalled to solve the present problems (ibid. :112). As a solution to the present problems of the black people in Africa, Fanon thus calls for such "return to the past" (Loomba, 2005: 153). African tribes were somehow "revenge" or honorbased" cultures in which the victim or his relatives were responsible for revenging the wrongdoer (Kaufman, 2013: 96-97), since to act otherwise was a proof to their lack of courage (ibid. :124). 
As a native of pre-modern African tribes, Moses has grown up in such system in which the revenger tries to restore his honor. It is in this condition that Moses enters an ambivalent state of being incorporating the tensions between colonial-and-not-pure Christianity and his negritude and tribal honor. As a good mission boy, he is taken to be different from other black servants. As Bhabha says, "It is precisely in that ambivalent use of 'different' - to be different from those that are different makes you the same - that the Unconscious speaks of the form of Otherness" (1994: 117). Du Bois too explains such black condition as "double consciousness", to be the other in a world in which the colonized is "inferior and uncivilized" (1999: ix). Thus the Negro lives in an ambiguous condition which is "extraordinarily neurotic" (Fanon, 2008 :148). Every neurosis thus derives from the "cultural situation" of the individual (ibid. :117-118). Consequently, learning in mission schools and working for the white has already established a special outlook towards the colonizer in Moses' mind.

Encountering the white society, Moses experiences what he did not expect; "instances in which the educated Negro suddenly discovers that he is rejected by a civilization which he has nonetheless assimilated" (Fanon, 2008: 69). As a black man he is useful only in case of good working. This is demonstrated by Lessing telling us that, "Dick did not like mission boys, they 'knew too much,' in any case they should not be taught to read and write: they should be taught the dignity of labour and general usefulness to the white man" (Lessing, 1973: 191). The development of such "dependency behavior" in the Negro is beneficial for him until he makes attempts at equalization with the European. It thus follows that the European becomes angry with the Negro pursuing equality with him and causes the Negro to replace his "rejection of dependence" with "inferiority complex" (Fanon, 2008: 69).

Initially not so drowned in a relationship with Mary, Moses is ready to leave her when she is too cruel to him, while at the end he cannot bear being dismissed, especially when he observes that Tony, as a white man for the romantic place of whom he has been serving all these years, is taking his place as Tony puts "his arm round Mary's shoulders" ordering Moses to leave the house (Lessing, 1973: 233). What hurts the black man most is to discover that in the realm of masculinity he occupies the black hole. The "abandoned" or "betrayed" black man feels "clamorous" under such identification. Equality with the white man is beneficial merely before asking for it; afterwards it proves dishonorable and insulting to the Negro. This is the path along which the black man "passes from psychological dependence to psychological inferiority” (Mannoni, 1964: 84). The Negro thus suffers identity crisis through such feeling of insecurity (ibid.: 61-62). Therefore, feeling abandoned by Mary and rejected by the white society, Moses develops abandonment-neurosis, discussed below. 


\section{The Black Man and the White Woman: Moses vs. Mary}

Moses experiences problems in the process of his negritude, and that is because of his encounter with the white woman. White women and black men are regarded as paradigms of white and black races respectively (Harding, 1986: 178). Thus, any tension between the two points at striking issues between the colonizer and the colonized in general. As mentioned above, settlers in South Rhodesia treated their native laborers as mostly dogs to be beaten. But they dismissed the fact that the natives of Lobengula's kingdom of Southern Rhodesia had such strong jealousy for the "chastity of their white women" (Hensman, 1900: 169). Never in contact with the natives since her childhood, Mary encounters black servants and laborers following the already established norms in the white society. She, like "every woman in South Africa," was "forbidden to walk out alone" because "they were nasty and might do horrible things to her" (Lessing, 1973: 70). Mary has been acculturated in her fear of the "black peril" (Fanon, 2008: 157), the proximity of African men to European women. Mary is already racist then, believing in the superiority of the whites over the blacks. While Dick, as the white man, rarely plays the master, Mary is contemptuous and cruel to black laborers because she does not "believe in treating them soft" (Lessing, 1973: 142). Halstead identifies the first type of racism among many as the "pre-reflective gut racism" (1988: 142), the intense hatred of people of a different race or culture resulting in "dominance, superiority, and aggression against certain members of society" (Kirton 2010: 57). Mary is terribly hostile to house servants and makes farm laborers work harder, reduces their break times, and decreases their payments in case of disobedience. As the master's wife in charge of the farm, black laborers, mostly male ones, must obey her.

Mary's first masterly orders on the farm inaugurate the relationship between the white woman and the black men in general, and her conflict with Moses in particular - as "Involuntarily she lifted her whip and brought it down across his face in a vicious swinging blow" (Lessing, 1973: 146). The scene is striking enough as Moses describes the reason of his idleness in broken English in a "ludicrous manner": "I ... want ... water." And then suddenly smiles and opens his mouth and points his finger down his throat (ibid.: 146). Since "most white people think it is 'cheek' if a native speaks English," Mary's “inarticulate rage” whips Moses in the face (ibid.: 146). Moses' English is an act of mimicry whose mere purpose, accompanied by his pointing to his mouth, ridicules the white race. According to Ashcroft et al., the colonized mimic the colonizers against their expectations. Such "fluctuating relationship between mimicry and mockery" unsettles the colonial dominance (1998: 13), and undermines the colonizers' authority (Loomba, 2005: 149). Tensions then intensify between Mary and natives because they expect their master to be a man, not a woman. 
While Mary's childhood plays "a traumatic role" in her behavior, and her mental state is continually deteriorating with social pressures (Büyü 89), she suffers from a sort of "tactile delirium", a sense of nausea to any touch by a man as Fanon defines the term (2008: 124). She "doesn't understand anything about sex or life" (Lessing and Ingersoll, 1994: 113). She feels "repelled by the thought of intimacies and scenes and contacts" (Lessing, 1973: 43); feels revolted when kissed (ibid.: 52), and has "a profound distaste for sex" (ibid.: 46) that makes her not a suitable wife for marital life with Dick. She also feels "nausea" when Moses touches her shoulders (ibid.: 186) that is a result of white women's "colonial fears" of rape by Negroes (Loomba, 2005: 139). Ironically, while Moses embodies the "colonial fears of African sexual prowess" (Roberts, 2003: 134), Mary suffers a lack of satisfactory sexual relationship with her husband.

This paradox leads Mary to develop an "intense emotional ambivalence" towards Moses (Georgescu et al. 2011: 27), and Moses turns into a projection of her repressed passions (ibid.: 29). Watching Moses washing himself, Mary's view is conveyed in a metaphorically sexual language: "Remembering that thick black neck with the lather frothing whitely on it, the powerful back stopping over the bucket, was like a goad to her" (Lessing, 1973: 177). "Thick black neck," "lather frothing whitely," and "goad" signify a threat of rape to the white woman. Lessing holds that the incident is on the model of a real scene which "was too directly sexual." The consequences of such observations develop within Mary, a woman with tactile delirium, the fear of rape by the black man.

Still keeping the white status quo, Mary treats her black servant as "an abstraction", "a machine without a soul" (Lessing, 1973: 188). But, unlike other natives, Moses calls her "madame" and follows "his desire to please her" to hear an approving word from her (ibid.: 190). In fact, in Fanon's words, the Negro wishes to be taken as white, and it is only a white woman who can do so by loving him and proving that he is worthy of white love. The Negro can thus be loved like a white man and becomes a white man (2008: 45). This requires that the Negro sleep with the white woman to enter "authentic" manhood (ibid.: 52). However, Mary's negrophobia is still a block to Moses' negritude, the common thing between them merely being the ambivalence of the space and double consciousness developing between them. As a white person, Mary feels the weakening of her control over her inferior and her increasing awareness of a sexual orientation towards him (Janik, 2002: 198). Moses' "powerful, broad-built body" enchants her (ibid.: 175), and she feels "helplessly in his power" (ibid.: 190). 
Moses then enters Mary's life not only as a "symbol of color conflicts" but also as the embodiment of "a disruptive life force" which henceforward directs Mary's long-repressed emotions (Thorpe, 1978: 12). In other terms, the white woman's secret about the black man is "part of the ineffable." What she desires is her annihilation sexually; since the "delirium of orgasm" cannot be achieved in practice, the white woman avenges herself by drowning in "speculation" (Fanon, 2008: 131132). That is why Mary habitually sits on the sofa speculating over what Moses does when he is tending the house. Further, Mary's nightmares and daydreaming infer psychological traumas. In those of her dreams in which Mary confuses her father with Moses, feelings of horror and incest are striking. In Freudian terms, the incestuous passion for her father is replaced with inclinations toward Moses, that is, the primary "incestuous taboo" is substituted by the "colonial taboo" (Georgescu et al. 2011: 29). Here the color bar, extremely internalized like the "infantile oedipal conflict”, does not permit her to accept Moses openly (Aghazadeh, 2011: 117).

Breaking the color bar, nonetheless, Mary cracks "the formal pattern of black-and-white, mistress-and-servant" through her personal relation with Moses (Lessing, 1973: 177-178). Still more, the similar state of living of both of black slaves and poor whites like Mary and Dick develops a sense of equality with the white race in Moses. "The phrase 'poor whites' [...] caused disquiet [...], but there was certainly a race division. [...] 'Poor whites' were Afrikaners, never British” (ibid.: 11). Although Mary and Dick are "British, after all" (ibid.: 11), the initial law of settlers held that "Thou shalt not let your fellow whites sink lower than a certain point;" lest "the nigger will see he is as good as you are" (Lessing, 1973: 221). This colonial anxiety or "cultural neurosis" places Mary in a subordinate position and a neurotic state in which she cannot control her actions and speech (Aghazadeh, 2011: 116). On the other hand, Moses' first touch of Mary is a "skin-to-skin contact" that dismantles the racial boundary between them and threatens not merely Mary's identity but also the identity of the entire colonial settlers in the region (Georgescu et al. 2011: 36). Although she loathes any touch by him, she is comforted "by his voice firm and kind like a father commanding her" (Lessing, 1973: 187). Moses is able to calm her, against her racist feelings. This is most striking when Moses orders Mary to drink water. "Drink, he said simply, as if he were speaking to one of his own women; and she drank" (ibid.: 186).

However, the Negro cannot help remaining a "phobogenic object, a stimulus to anxiety"; "Negro-phobogenesis" is thus defined as the anxiety stimulated by the Negro (Fanon, 2008: 117). Mary develops such phobia, especially when she thinks of Moses touching her. As Fanon says, any physical contact is enough to evoke anxiety because it is the first step in the cycle of "touching, caresses-sexuality" 
(2008: 120). Negrophobic women, who have mostly experienced unusual sex lives due to the lack of suitable partners of their own race, consider the Negro having powers lacking in them (ibid.: 122). Once Moses establishes his authority over Mary, her Negrophobia and Negro-phobogenesis grow tense; she seeks support from Dick "against the presence of the native" (Lessing, 1973: 187). And later, "It was a nightmare, the powerful black man always in the house with her, so that there was no escape from his presence. She was possessed by it, and Dick was hardly there to her" (ibid.: 206). Mary is pictured as Moses' vulnerable victim while her husband is a mess.

Accordingly, Mary gradually develops "a fear of all physical intimacy" (Roberts, 2003: 134), or "tactile delirium" (Fanon, 2008: 124), specifically towards Moses. Such feeling causes Mary to finally find a safeguard against Moses behind Tony. Moreover, abandoning Moses for a vacation at the end of the story has already been made out. Moses, therefore, feels abandoned by the source of his illusory whiteness, the white woman. Such "abandonment neurosis" (Fanon, 2008: 52) accompanied by Moses's trauma and inferiority complex, results in a "posttraumatic stress disorder" featured by the fact that the traumatic subject cannot effectively deal with the situation. Moses' trauma thus ends up in murdering Mary (Kirton, 2010: 78), a cathartic act at the apex of his rage.

Moses' ambivalent state of being is significant here. Bhabha defines ambivalence as "the complex mix of attraction and repulsion that characterizes the relationship between colonizer and colonized." Ambivalence derives from the fact that the colonized is never absolutely against the colonizer. Thus, "complicity and resistance exist in a fluctuating relation within the colonial subject" (1994: 116). However, ambivalence dismantles the authority of the colonizer as the colonized mimic them against their expectations. Such oscillating condition between mockery and mimicry dismantles the colonial dominance (Ashcroft et al. 1998: 12-14). However, ambivalence does not merely indicate the traumatic state of the mind of the colonial subject but also the "workings of colonial authority" and "the dynamics of resistance" (Loomba, 2005: 149). Accordingly, the Negro should no longer submit to the dilemma "turn white or disappear;" he should try to actualize "a possibility of existence." If he cannot deal with social problems because of his skin color, advising him to remain in his place is nonsense; but once he makes sense of his real motivations, he should rather perform an action or remain passive regarding the source his trauma (Fanon, 2008: 75). The final insult against Moses by Tony ignites the former's sense of honor which is only achievable through an act of revenge. The Negro's mission among the whites reaches its end when he is no more "palatable in a certain way" (ibid.: 135). Tony's presence as a white man with a safe passion for Mary presupposes throwing Moses out as garbage, 
ending his mission in sympathizing with Mary, and thus causing him to rise in defense of his honor than remain passive.

\section{Double Effect Reasoning and Moses' Act of Murder: Revenge for Honor}

Since "attempts at a hallucinatory whitening" (Fanon, 2008: 74), manifested by Moses trying to please the white lady in order for self-identification, fail him and he is dismissed, the black man revenges his honor. As a crime including a murder committed willingly by Moses, Moses' act of revenge can be discussed through DER for its permissibility or illegibility in defense of or against Moses, as the issue is interracial violence. For DER to permit an action with both good and evil aspects, four essential conditions should be actualized: "the act in itself is good or indifferent; the agent intends the good effect and not the evil effect; the good effect is not produced by the evil effect; and there is a proportionately grave reason for causing the evil effect" (Cavanaugh, 2006: 26).

Double effect considers "harmful effects that are regretfully intended as part of the agent's means" to be impermissible and "harmful effects that are regretfully foreseen as side effects of the agent's means" to be permissible (McIntyre, 2011: 12). According to Aristotle, some acts are wrong in nature, such as adultery, envy, theft, murder, among many, and the subject willingly doing them cannot be justified. Likewise, the first criterion in DER reflects the impermissibility of such acts (Cavanaugh, 2006: 27). In the second condition, the agent does not will any evil, "neither as his means nor as his end" (ibid.: 28). The third condition is taken as "redundant"; it confirms the fact that the agent may not will the evil effect as an end or as a means or, thus replicating the second condition (ibid.: 29-30). And the fourth condition compares "one's reasons for doing the good to one's reasons for avoiding the evil." Action requires the appropriate "gravity" of one's reasons for causing the good (ibid.: 31). As the third condition is redundant, in a simplified form, conditions turn into three: "an action independent of its evil effect is not intrinsically wrong; the agent intends the good and not the evil, neither as a means or as an end; the agent has "proportionately grave reasons" for his/her action, taking into account "relevant obligations, comparing the consequences," and regarding "the necessity of the evil," being cautious enough "to eliminate or mitigate it" (Cavanaugh, 2006: 36).

Moses' case is concerned with revenge and honor. Honor is morally grave, while murder is not. However, in the case of Moses and his traditional revenge/ honor-based society, honor is attained only through murder/revenge. The "revenger is motivated by honor," and failure in exacting revenge will be shameful or brings dishonor (Kaufman, 2013: 110). As the chief value of pre-modern societies, honor 
is an individual's "dignity or self-respect." Attacking an individual was attacking his/her honor, so honor was defended through "a physical confrontation with the wrongdoer." The side effects of revenge, even the cruelest ones, are thus rated as "secondary byproducts" and not as essential motivations in defending honor (ibid.: 121). Honor thus includes freedom as its central feature; a slave embodies dishonor while a free man personifies honor through showing courage against any threat of harm. Thus, "the supreme test of honor is courage" (ibid.: 124).

Kaufman talks about "revenge cultures" in which a victim or his relatives were supposed to revenge the wrongdoer, while in modern cultures, the legislative system judges for all (2013: 96-97). However, the complexities of social relations in some revenge or honor-based cultures make it hard for outsiders to make sense of the fact that these cultures cannot bear even "trivial insults." Such societies are somehow "insanely sensitive in the matter of honor" (Kaufman, 2013: 99). In revenge or honor-based cultures, the label of cowardice was not tolerating as far as it meant that one might not avenge a wrong against oneself. Thus, in pre-modern revenge systems insults and disrespect are taken as moral wrongs and it is moral to respond to them. The point is that systems are different "on just what wrongs count" (ibid.: 100). Therefore, the punishment of the white retributive legislation for a white person, like Charlie Slatter who kills a black man "in a fit of temper," is merely 30 pounds, while the penalty for a black man, like Moses, killing a white woman and unfairly accused of theft is hanging. Likewise, the penalty for dishonoring someone in the pre-modern black revenge system is the oppressor's life; Moses thus murders Mary to defend his honor as a black man defending his negritude.

Killing Mary is not accidental but intentional. But, according to DER, the question rises whether killing here is Moses' intention or his means to an end, his honor. The good end being the preservation or restoration of Moses' honor, Mary's murder becomes the bad side effect. Killing her is not the intentional means to save his honor, but saving his honor includes the evil side effect of her annihilation. It is impermissible to bring about her death intentionally. Rather, her murder is the foreseen side effect of retrieving back his honor. This is when revenge is called upon; Mary's death is the good effect itself, the bad effect being committing a homicide. Death of an oppressor white woman by an oppressed black man is the good effect for Moses as the suffered agent. Killing is thus a justifiable act for him to save his honor. If he wants to defend it, killing Mary is inevitable but not meant, and thus it seems permissible. Accordingly, as far as revenge against Mary is justifiable through Moses' mentality for the sake of his honor, the three conditions of DER manifested in this case are as such: Honor is morally and spiritually good independent of any evil effects; Moses intends the defense of his honor and not Mary's death neither as an end nor as a means; Moses has proportionately 
grave reasons for murder, that is, his honor; addresses his obligations; reflects on the consequences; avoids unnecessary harm.

The first condition is concerned with Moses' motivation in murder. As something spiritual honor includes a more severe suffering than physical harms. Aquinas considers "scandal" "to be words or deeds that occasion another's spiritual ruin. Homicide harms another's corporeal life; scandal, his spiritual life. Accordingly, scandal harms another more gravely" (Cavanaugh, 2006: 14). That is why Moses decides to restore his honor against that scandal by the white race, since his failure in reviving his honor is a symptom of fear which is against his negritude.

The second condition holds that Moses does not intend Mary's death either as a means or as an end for the sake of his honor; it is only a side effect. "Intended' refers to ends and means, while 'foreseen' refers to side effects;" means, side effects, and ends are all related to the agent and have ethical significances (Cavanaugh, 2006: 75). In other words, DER holds that the revenging agent can claim to foresee but not intend harm in permissible cases, while he cannot claim so in impermissible ones (ibid.: 85). Honor shall be restored and whatever happens in the conflict is a foreseen but not intended side effect. Although murder is wrong in itself, but the nature of the oppressor as that of a cruel racist who has dishonored a black man and dismissed him against his decency is not moral either. And it is necessary that the murder be looked upon through the black lens and not through that of the white mission in Africa. In the interracial struggle for defense and honor, such murders are inevitable.

Regarding the third condition, on the small scale, personal revenge includes "a strongly emotional component" intensified under "strong social pressures" (Kaufman, 2013: 97). Moses postpones Mary's murder as he does not kill her in the store when they are alone (Lessing, 1973: 247), or during the last day of Mary's life when Dick and Tony are out on the farm. Pressures on Moses reveal themselves in such static moments of his life as he does not act against Mary but merely hides and speculates until his full moon turns him into a murderer. Whether he has been waiting for the appropriate moment of revenge or overcoming his fear, what is evident is that speculation on revenge is on the run: "Though what thoughts of regret, or pity, or perhaps even wounded human affection were compounded with the satisfaction of his completed revenge, it is impossible to say" (Lessing, 1973: 256). Moreover, Moses is aware of the consequences of his action, his own punishment and no improvement in the condition of the black race. He also disdains from further harm to the white community as helets Tony live in his sleep. DER excludes unnecessary harm or requires the lessening of any necessary harm, "proportioned to its end," and as Aquinas holds, 
it is impermissible to use more-than-necessary violence (Cavanaugh, 2006: 33).

It is necessary here to quote Fanon that "to the identical degree to which [the colonizer] society creates difficulties for [the black individual], he will find himself thrust into a neurotic situation" (2008: 74). When the Negro contacts the white world, the weakness of the psychic structure of the Negro causes the collapse of his ego. He thus "stops behaving as an actional person." His behavioral objective being the guise of the white man to achieve true white worth, the black man needs "self-esteem" (ibid.: 119). Fanon believes that "psychic trauma" occurs when the colonized realizes his otherness, that he can never achieve the desired whiteness and get rid of the devalued blackness. Bhabha, as Loomba understands him, expands this issue to suggest that "colonial identities" are always in a state of "flux and agony", and that it is always with regard to the position of the Other that colonial ambitions are articulated (2005: 148). Dismissed from that desire by Tony's presence, Moses, "to whom [Mary] had been disloyal, and at the bidding of the Englishman (Lessing, 1073: 254), develops what Germaine Guex calls "abandonment neurosis" (Fanon, 2008: 52).

Abandonment neurosis includes an "affective self-rejection" which "invariably brings the abandonment-neurotic to an extremely painful and obsessive feeling of exclusion, of having no place anywhere, of being superfluous everywhere in an affective sense." The sense of otherness in such person infers "a shaky position" in which he/she is always likely to be refused (Guex, 1950:35-36). The abandonmentneurotic

views everything in terms of himself. He has little capacity for disinterestedness: His aggressions and a constant need for vengeance inhibit his impulses. His retreat into himself does not allow him to have any positive experience that would compensate for his past. Hence the lack of self-esteem and therefore of affective security [...]; and as a result there is an overwhelming feeling of impotence in relation to life and to people, as well as a complete rejection of the feeling of responsibility. Others have betrayed him and thwarted him, and yet it is only from these others that he expects any improvement in his lot. (ibid.: 27-28)

As a "traumatic experience", what befalls on Moses changes his "psychological, biological, and social equilibrium" in a way that the recollection of one specific event taints all other experiences, forcing him to merely reflect upon that experience and dismiss the present (van der Kolk \& McFarlane, 1998: 488). Mary's betrayal, as the 
sum of all the cruelty he has suffered under colonization, is enough to enrage him toward murder. He has repressed his sufferings all through these years; they have become "latent forms of psychosis", which reveal themselves as the consequences of a traumatic experience (Fanon, 2008: 62).

Intermingled with Moses' neurosis is his native background. When "old tribal restrictions" among the Zulus and Matabele were abolished through Christianity, the natives with evil intentions but under those restrictions probably did what they desired in the newly gained freedom. Accordingly, the new evil is generally attributed to attempts at civilizing and Christianizing the natives during colonizers' missionary endeavors which evaporated traditional boundaries. In African towns, there were men and women with Christian names leading bad lives. However, it was not clear whether they were real Christians or merely natives with Christian names. If they were Christians, being members of any mission and their probable dismissal "on account of their failings" were of real concern. If they were Christians and part of any mission, they were on the same level with people in England, where it was not supposed "that the failings of individuals prove the uselessness of Christianity" (Knight-Bruce 66-67).

Moses, as a mission boy, is a "decent" Negro whom Dick has brought into his household. He is wise enough to use the courtesy he has learned as a mission boy. One of the good aspects of mission-work in Africa was "the rapidity with which black heathen savages" distinguished between "indifferent white men," who did not behave well, and the "missionaries" or those who tried to be fair to them (Knight-Bruce, 1985: 69). Missionaries had good servants who were in fact made to work well (ibid.: 71): they had to get up early, work consistently, and make much of time during the day. Although they were probably paid less than what was paid in European camps, natives preferred mission camps where they were "treated fairly" (ibid.: 72). As a mission boy and an educated Negro, Moses seems to have gone through all these experiences, as he works orderly in Dick's house, and thus prefers fair treatment by his masters. He once forgave Mary after the whipping scene, but altogether forgiveness was unlikely ever observed "as a virtue" in African tribes (Knight-Bruce, 1985: 87). That is because the orientation to praise "strength" among natives made it difficult to teach them part of Christianity. Under the same conditions, natives preferred working for a white master who does not beat them than for a beating one, but they kept their admiration for the latter. "He represents strength-a chief's characteristic; he is the greater chief of the two" (ibid.: 88). That is why Moses does not kill the strong Mary who whipped him in the face, the woman of strength as a powerful chief worthy of admiration, but he kills the weak Mary hiding behind a white newcomer. Accordingly, Moses' act of murder is 
permissible based on his own conception of betrayal and honor. Mary's getting away from the farm and her affectionate relationship with Tony ignite in Moses a sense of disloyalty from Mary. Thus, he sees Mary as an unfaithful mistress in his own manner and she has to pay for it with her blood.

To sum up, conventional Double-Effect principles emphasize the value of achieving the good end with the least possible harmful side effect (McIntyre, 2011: 11). The question here is whether murdering a white person by a black servant is justified. Because it is an interracial issue, it has certainly proponents and opponents. However, killing the oppressor white master is a good thing in the black eye, while the murder of a white woman by a black servant is terrible in the white eye. As Roberts says, Mary's body may stand for colonialism to be ruined by Africa (2003: 135). Thus, Moses becomes the prototypical African man for the whites to see and fear him (Lessing and Ingersoll, 1994: 100). However, Moses' submission after the murder solves the case. He commits a murder and defends it with his surrender, while he could easily escape the scene long before any one catches sight of Mary's body.

\section{Moses' Act of Surrender}

Moses finally reaches the decision to surrender himself at the end of his mental journey. Under Lobengula, as mentioned above, native criminals surrendered themselves willingly as there was no escape and it was in accordance with their courage and honor. "Over an ant-heap" is the place over which Moses is standing at the end of the story, as described in the first chapter of the novel, to represent his final state: traditional "impalement" or its white version "hanging", as he is going to be hanged for Mary's murder: "It was the tradition to face punishment" (Lessing, 1973: 14). But here seems to be another justification for his surrender not exclusively out of fidelity to his native tradition.

Moses revenges for honor which is his end and is worth fighting for. It is the essence of his negritude and defines the value of his pre-modern world; it is his dignity and self-respect. As a native, his honor and courage make the same word. Committing a crime, justified or not, does not allow him to escape. He must surrender to keep his tribal tradition, to keep the moral code of the late King Lobengula, to die with honor. As Kaufman says, in the pre-modern world and revenge or honor-based cultures, the assumption was that "no one could properly demonstrate his honor without his being willing to risk everything for it, including (indeed, especially) his life" (2013: 125). Moses' surrender is an act of negritude; by surrendering he is restoring his black roots. It is not out of fear from the white that 
he surrenders but as a form of resistance and authenticity over the white master to reveal his own courage. Members of revenge or honor-based cultures had their own standards in categorizing harms which were to be revenged and the harshness required to do so (Kaufman, 2013: 100). Such cultures were ruled by "the principle of strict liability:" being responsible for a committed wrong, especially a death, either accidental or deliberate, justified or not (ibid.: 105). Accordingly, in the final scene of the novel, Moses most willingly and knowingly awaits the police and surrenders himself. In fact, "In the courage to risk one's life in defense of one's principles, honor masters the all-too-human fear of death and the more mundane pull of the desire for self-preservation" (Krause, 2002: 128). Moses knows his coming death but he still surrenders because of his honor.

\section{Conclusion}

Lessing seems to be criticizing England for its colonial policies and not even its lack of ability to teach true Christianity to Africans due to the maltreatment of Africans. Her novel suggests that races are unable to understand each other in full. This is mostly represented in the opening chapter when Tony Marston realizes that Moses will be hanged as he has murdered a white woman, without any sympathy for Moses. Tony is unable to understand the black race, since his white worldview is defected. And the fact is that Moses does not kill Mary after the whipping scene but after her betrayal and intimacy with Tony. This is a fact which should be investigated from the Moses' own viewpoint towards life, which derives from his tribal belief regarding the defense of his honor which can merely be achieved through tribal revenge. Revenge is sometimes undertaken against an agent close to the aggressor. On the other hand, among pre-modern cultures, the presumed best form of revenge was punishing the aggressor face to face. On the other hand stands the corrupted picture of Christianity as shown to the natives. As a schoolboy trained in Christianity, Moses observes a white society against the pure Christian code of peace they are seemingly pursuing and trying to propagate. Moses' revenge thus finds a broader scale of meaning than the mere murder of his oppressor. Metaphorically speaking, what Moses does is a two-edged sword of revenge: he kills the white woman, both as his oppressor and as the most notable attraction of the white race. Moses personally attacks the colonizer, face to face with its weak point, the white woman; hence, the "black peril".

Moses' revenge and surrender both signify his African honor and resistance against colonization. In such dilemma of love and hate, revenge and forgiveness, represented through Moses' postponement of his revenge for at least one day after his dismissal by Tony and his subsequent surrender without resistance, Moses' 
ambivalent state of living leads him to an act of murder and willing surrender which seem both justified on the grounds of his African honor and Double-Effect Reasoning, all rooted in his negritude and Christian trainings. Moses' crime of murder, though blasphemous under colonial Christianity which already condemns the black race because of their skin, reveals a code of honor in negritude and its defense; Moses wreaks the colonial oppression on the colonizers themselves still knowing that Mary will be sacrificed. Mary's death thus cannot be regarded as the result of a former lover's jealousy or the brutality of a black Negro. It is an honorbased murder/revenge. Moses' final heroically surrendering himself to further defend his African tribal traditions of punishment for a crime thus move in parallel lines with negritude and application of black ethics, a case study of South Rhodesia.

\section{References}

Aghazadeh, Sima. 2011. Sexual-Political Colonialism and Failure of Individuation in Doris Lessing's The Grass is Singing. Journal of International Women's Studies, 12(1), 107-121.

Alkali, Mohammad, et al. 2013. Dwelling or Duelling in Possibilities: How (Ir)relevant are African Feminisms? GEMA Online Journal of Language Studies. 13 (3). 237-253.

Ashcroft, Bill, Gareth Griffiths, and Hellen Tiffin. 1998. Key Concepts in Post-Colonial Studies. New York: Routledge.

Bhabha, Homi. 1994. Remembering Fanon: Self, Psyche and the Colonial Condition. Colonial Discourse and Postcolonial Theory. Eds. P. Williams and L. Chrisman. New York: Columbia UP. 112-123.

Büyü, Gül. 2007. A Freudian Study of The Grass Is Singing, Aylak Adam, and The White Hotel. Diss. Middle East Technical University in Istanbul.

Cavanaugh, T. A. 2006. Double-Effect Reasoning Doing Good and Avoiding Evil. Oxford: Oxford UP.

Dodds, Glen Lyndon. 1998. The Zulus and Matabele: Warrior Nations. London: Arms and Armour Press.

Du Bois, W.E.B. 1999. The Souls of Black Folk. Ed. Henry Louis Gates, Jr and Terri Hume Oliver. New York: W. W. Norton \& Co.

Fanon, Franz. 2008. Black Skin, White Mask. London: Pluto Press.

Fry, Peter. 2007. Spirits of Protest: Spirit-Mediums and the Articulation of Consensus among the Zezuru of Southern Rhodesia (Zimbabwe). Cambridge: Cambridge UP.

Georgescu, Elena Anca, Angela Stanescu and Gabriela Popa. 2011. Cultural and Psychological Border Crossings in Doris Lessing's The Grass is Singing. International Journal of Arts and Sciences 4(1), 23-38.

Guex, Germaine. 1950. La Névrosed'abandon. Paris: Presses Universitaires de France. 
Halstead, Mark. 1988. Education, Justice and Cultural Diversity: An Examination of the Honeyford Affair, 1984-85. London: Falmer Press.

Harding, S. 1986. The Science Question in Feminism. New York: Cornell UP.

Hensman, Howards. 1900. A History of Rhodesia. Edinburgh and London: William Blackwood and Sons.

Janik, D. I. 2002. Modern British Women Writers: An A to Z Guide, eds. V. Jaulkand E. S. Nelson. New York: Greenwood Press. 196-205.

Kaufman, Whitley R. P. 2013. Honor and Revenge: A Theory of Punishment. New York: Springer Science and Business Media Dordrecht.

Kirton, Teneille. 2010. Racial Exploitation and Double Oppression in Selected Bessie Head and Dorsi Lessing Texts. Diss. University of Fort Hare (East London Campus).

Knight-Bruce, George Wyndham Hamilton. 1985. Memories of Mashonaland. Cambridge: Dodo Press.

Krause, Sharon. 2002. Liberalism with Honor. Cambridge: Harvard UP. 2002.

Lessing, Doris and Earl G Ingersoll. 1994. Doris Lessing: Conversations. Eds. Doris Lessing and Earl G. Ingersoll. Ontario: Ontario Review Press.

---. The Grass IS Singing. 1973. Oxford: Heinemann.

Loomba, Ania. 2005. Colonialism/Postcolonialism. 2nded. New York: Routledge.

Mannoni, O. 1964. Prospero and Caliban: The Psychology of Colonization. New York: Praeger.

McIntyre, Alison. 2011. Doctrine of Double Effect. In The Stanford Encyclopedia of Philosophy. Ed. Edward N. Zalta. <http://plato.stanford.edu/archives/fall2011/entries/double-effect/>.

McCulloch, Jock. 2000. Black Peril, White Virtue: Sexual Crime in Southern Rhodesia, 1902-1935. Indiana: Indiana University Press.

Roberts, Sheila. 2003. Sites of Paranoia and Taboo: Lessing's The Grass is Singing and Gordimer's July's People. In Bloom's Modern Critical Views: Doris Lessing. Ed. Harold Bloom. Philadelphia: Chelsea House Publishers. 127-144.

Schlueter, Paul. 1973. The Novels of Doris Lessing. Carbondale and Edwardsville: Southern Illinois University Press.

Thorpe, Michael. 1978. Doris Lessing's Africa. London and Ibadan: Evans Brothers.

Van der Kolk, Bessel and Alexander McFarlane. 1998. The Black Hole of Trauma. In Literary Theory: An Anthology. Eds. Julie Rivkin and Michael Ryan. Oxford: Blackwell Publishing Ltd. 487-502. 